\title{
THE EFFICIENCY OF STRUCTURAL SUPPORT AND IMPACT ON ECONOMIC AND SOCIAL INDICATORS
}

\author{
Daiva DUMCIUVIENE, Alina STUNDZIENE \\ Department of Economics, School of Economics and Business, Kaunas University of Technology, \\ K. Donelaičio g. 73, 44029 Kaunas, Lithuania
}

Received 28 January 2015; accepted 10 May 2015

\begin{abstract}
The economic and social cohesion is one of the economic objectives of the European Union. It is, therefore, important to analyse the impact of policies of the European Union on cohesion. The establishment of the common market still did not offer a solution for economic problems faced by the Member States. The economic and social cohesion is very important to strengthen the political and economic development of the Member States. This article includes the analysis of Lithuanian economic environment compared with the other Member States and the impact of EU structural funds on economic growth of the country. The detailed analysis of the correlation between funding and economic and social indicators of Lithuania showed that there is the significant direct relationship between the funding and the direct foreign investments per inhabitant. The significant correlation between EU support and other economic and social indicators was not found. Nevertheless the EU funding is undoubtedly useful and necessary to promote the economic growth. The efficiency of the use of EU funds is the largest problem and the task achieving the maximum benefit for the economics of Lithuania.
\end{abstract}

Keywords: EU funds, EU cohesion policy, structural support, economic growth, economic development, efficiency of EU funds, impact, Lithuania.

JEL Classification: D31.

\section{Introduction}

The participants of any system experience the losses or wins due to the redistribution that is practised in all the political systems by different methods. The participants can include the countries, regions, different social groups and even individuals. The right distribution can be an important factor determining the continuity of the integration process. An increasing effort is being made seeking for the sustainable development including the regional

Corresponding author Daiva Dumciuviene

E-mail:daiva.dumciuviene@ktu.lt 
integration in the European Union. The EU regional policy is aimed at the reduction of social and economic differences between the Member States. It supports the creation of places of work, encourages the competitiveness, the economic growth, the pursuit of higher life standards and the sustainable development. The objectives of economic and social cohesion are extremely important for strengthening political and economic development in the EU Member States (Basile et al. 2007).

The main objective of cohesion policy is to reduce the gap between different regions, particularly the differences between developing and developed regions. It is the instrument of financial solidarity and the measure of economic integration. The objective "to promote economic, social and territorial cohesion and solidarity of the Member States" was confirmed by the Treaty of Lisbon (2007). The economic, social and territorial cohesion has the aim to reduce the economic and social differences in development of different regions. The European cohesion policy is more than the simple redistribution of funds. It is the raise of efficiency in the developing regions. The Strategy "Europe 2020" introduces three initiatives of growth: smart growth (promotion of knowledge, innovation, education and digital society), sustainable development (economical use of resources, increasing of economic competitiveness) and integral growth (seeking for high level of employment and economic growth ensuring social and territorial cohesion).

The Treaty of Rome notes the homogenous development of economic activities and sustainable development. The aim of the general policies of agriculture, transport, competition and trade is to reduce the differences between the countries and regions. Today the main aim of the European Union seeking for social and economic cohesion still remains the promotion of economic growth and efficiency by integration of the factors of production and commodity markets. At the same time the structural changes can negatively influence the particular society sectors by regional and social aspects. Therefore, the issues of redistribution are the constant subject of political debates.

The theories of economic growth were analysed by D. S. Cho (2004), P. Krugman (2003), A. Rugman and D'Cruz (2005), W. R. Cartwright (2001) and others. The problems of economic growth in Lithuania were studied by Z. Lydeka and A. Gineitas (1994), D. Dumciuviene (2011), V. Snieska (2008) and others. In spite of the great interest in the issues of economic growth, the theoretical argumentation remains one of the most difficult and complicated issues. It can be seen from the variety of the theories that explain the economic growth.

In the context of the European Union, Lithuania is a unit aiming at the creation of modern and competitive economics. However, the regional policies go further beyond one level of integration. Lithuanian regional differences must also be considered. That is why it is necessary to define European regional policies as well as the national regional policies of each member country.

In this article the authors discuss the impact of EU cohesion policy on an economic growth focusing on the measures of redistribution and the implementation of EU policies which are aimed at the economic and social cohesion.

The object of the research is the appliance of the EU financial funds in Lithuania aiming at economic and social cohesion. 
The aim of the work is to analyse the impact of the EU structural funds on Lithuanian economic and social development. Herewith it will show the efficiency of use of EU funds, i.e. if the support let to improve economic indicators of the country then the conclusion that the EU funds are used effectively can be made and vice versa.

The research methods used in this work include literature and statistical data analysis, correlation, causality, regression and time series analysis.

\section{The theories of economic growth}

The welfare distribution between the participants of integration process is an important political and economic problem. The main aim is to promote the economic growth in the developing countries. The theoretical arguments are used to explain how the integration influences the differences of economic development.

According to the theory of convergence, the economics converge in the integrated economies under the influence of rather strong regulation mechanisms (Rehme 2006). It means that there is not any necessity to conduct the regional policies. The competition policy and the removal of the barriers to free movement of goods, resources and technologies are enough to reduce the regional differences.

Another theoretical explanation states that the divergence is also possible. It depends on the development of the countries (regions). The regions that have the technological advantage attract the investment. At the same time the labour force is inclined to move to the regions or territories where the conditions for the career are better (Eckel 2007). This deepens the regional differences even further. The supporters of the theory state that the governmental actions are necessary aiming at the regional convergence.

The new theory of growth emphasises the significance of market access, technological change, human capital, international competitiveness, economy of scale and institutional efficiency (Kutan, Yigi 2007).

The issues of redistribution can rise inside the regions/countries and between individuals. The resources must be redistributed between the sectors inside the regions, and the companies must transfer their activities from non-competitive sectors to the ones where the rate of employment would increase. If such redistribution is not performed, both winners and losers can appear in the process of integration. An inability of the regions to transfer the resources from one business sphere to another shows the internal structural inflexibility. With reference to this point of view, the integration itself does not ensure the convergence: the political actions and measures must be invoked (Hall, Smith 2001).

Hence, the governments pursue the policy which impacts the welfare redistribution between the individuals and regions. The member states can use three main variables: selection of the territory supported, intensity of the support in selected territories and selection of the budget size for regional policy. The efficiency and the equity are two reasons of the implementation of such policy. Both of them contain the regional and social aspects, for instance, a governmental program for greater labour mobility or a retraining program under the new conditions of industry restructuring (Farrell 2004). 


\section{The effectiveness of EU structural funds and impact on the economic environment of the country}

Border control for goods, services and capital was abolished on January 1, 1993 following the program of European Single Market.

Particular policies have also been engaged implementing the program of European Single Market,. The EU competition policy can be described as the controlling mergers, monopolies and governmental support (Snieska 2002). The aim of such policy is to promote the efficient functioning of market forces limiting both the domination of big corporations and the governmental intervention (Hassler et al. 2005). The removal of barriers for competition has the consequences similar to the removal of trade barriers.

The advantages of free trade encouraged the founders of the EU to follow the principle of free internal movement of goods. The multilateral trade policy is implemented through the World Trade Organisation. The contracts have been made with the countries joining the EU, and at the same time the EU developed the agreements of free trade with the third countries.

The EU promotes the policy of research and technological development (R\&TD). It is implemented by the arranging joint long-term research programs. The efficient development of R\&TD in the production sector enables to reduce the dependency of the countries on lowskilled labour force as well as on the low-tech activities. The development of R\&TD as well as the development of infrastructure can contribute to the increase of competition in particular sectors.

Maynou et al. (2014) analysed whether the Structural and Cohesion Funds have contributed towards convergence between the Eurozone countries during the past two decades, 1990-2010. The results of the spatio-temporal econometric model specified in their paper illustrated that these funds have positively contributed to the gross domestic product per inhabitant (GDPPC) growth of receiving regions, thus allowing them to reach (conditional) convergence.

Meanwhile the results of the research of Bouayad-Agha et al. (2013) suggest that Objective 1 programs have a direct effect on regional gross domestic product per capita growth rates, whereas total Structural Funds do not.

Leonardi (2006) stated that the peripheral and less-developed regions and countries have not fallen behind the developed countries of the core during the ten years, but moreover they have grown at faster rates than the core areas. The policy has helped to reduce the socio-economic disparities between core and peripheral areas.

The abilities of the EU support to achieve the objectives depends on the several factors. The main criterion for the access of EU structural funds is that EU funds should be used purposefully and efficiently. It is important to use the EU funds efficiently in all the country and ensure that the developed mechanisms meet the national priorities.

Bachtler and Wren (2006), Mendez (2011, 2013), Bachtler and Gorzelak (2007), Mirosnika et al. (2014), Enguix et al. (2012) explored the effectiveness of European structural funds. Most of them stated that - on average - structural funds are ineffective. Ederveen et al. (2006) founded that structural funds are effective for countries with a "proper" institutional framework. The latter result is obtained for a wide range of conditioning variables, such as the openness, institutional quality, corruption and indicators for good governance. 
In 2010 Mohl P. and Hagen T. announced the article in which they analysed the use of the ES funds for regional development. The authors state that the EU structural funds often finance the projects that are not economically efficient because they have been affected by the political motives. Furthermore, since the projects financed from the EU structural funds have to be co-financed, the opportunity to use the structural funds in the public sector changes the investment projects of the public sector reducing the efficiency. It can damage the regional development.

The investment from the EU structural funds can cause the adverse economic consequences. It should be considered that the projects are selected by the particular criterions, but not by the market needs that can change faster than the period of project preparation and implementation.

The use of the EU funds can contribute to the business development. The structural support is assigned only for the sectors which have the priority of the EU support. The sectors not assigned for such funding face increasing difficulties to compete in the market. The companies entitled to the EU funding work under the exceptional conditions and successfully compete with the ones that are not entitled to the funding. Thus, the EU funds become a tool using which the government but not the market distributes the resources for the formation of economic structure.

However, the real beneficiaries are often not the ones that acquire the support. It happens when the significant funds assigned for one sector artificially raise the demand of resources in this sector which, in turn, raises the price. Thus, the resource providers become the real beneficiaries. It means that the EU support payments in the particular sectors cannot be accurately captured.

Access to the EU funds can also change the motivation of the private sector. The use of such funds can become not a solution, for example, to the lack of knowledge or skills, but one of the main business aims and the way to survive. The resources which could be used seeking to create the value added for the economics of the country would compete not for the quality of goods or services to meet customers' needs, but for the support which does not create any value added.

The market participants can aim at influencing the decisions of the EU fund managers about the fund assignment, absorption control and so forth seeking to benefit themselves,. Thus, absorption of the EU funds makes the conditions for the greater corruptionin the country.

Rodríguez-Pose A. and Fratesi U. (2004) research showed the failure of European development policies to fulfill their objective of delivering the greater economic and social cohesion by examining how European support was allocated among the different development axes in Objective 1 regions. They found that despite the concentration of development funds on infrastructure and, to a lesser extent, on business support, the return to commitments on these axes was not significant. Support to agriculture has short-term positive effects on growth, but these wane quickly, and only investment in education and human capital - which only represents about one-eight of the total commitments - has medium-term positive and significant returns. 
In 2009 Katsaitis and Doulos analysed the links between the EU structural funds and the direct foreign investment in $15 \mathrm{EU}$ countries. It was established that the impact of structural funds on direct foreign investment is not always positive and depends on the quality of institutional infrastructure of the country. The structural funds can slow down the development and attraction of foreign investment in the countries with high level of corruption and poor public institutions.

Summarising the analysis of the impact of EU structural funds, it can be stated that the benefits of the EU structural funds highly depend on how and in what economic environment (taxes, regulations, business conditions, public institutions and transparency) these funds are used.

\section{Implementation of political measures}

Lithuania gained a possibility to use the EU structural assistance when it became a full member of the EU from 1 May 2004. Total assistance granted for the implementation of the Single Programming Document of Lithuania for 2004-2006 (SPD) and the Cohesion Fund Strategy for 2004-2006 amounts to 1,721 million euro: 895 million euro for the implementation of the SPD projects and 826 million euro for the Cohesion Fund projects (Ministry of Finance of the Republic of Lithuania 2010a, 2010b).

EU structural assistance for 2007-2013 is allocated from the European Social Fund, European Regional Development Fund and Cohesion Fund under the Lithuanian Strategy (i.e. the assistance granted totals more than 6.7 billion euro).

It is difficult to estimate quantitatively the impact of the EU structural funds on the economics of the country. In order to make that, it is necessary to determine the direct and indirect impact on the different measures. The latter, by the way, can be negative as it was previously discussed, for example, the direct support for a company distorts the market relations and makes the conditions for unequal competition (Shelton 2007).

Batterbury S. C. E. (2006) provides a critical assessment of the evaluation of European Union Cohesion policy, focusing on the current regulatory framework, and the difficulties to achieve rigorous and useful evaluation outputs. His research argues that the evaluation framework for cohesion policy is limited to three core purposes: accountability, improved planning, and quality and performance, but that it would benefit from widening this to include other functions. The decentralization of evaluation to the Member States means the evaluation of Cohesion policy relies on the presence of a pre-existing evaluation culture and skills base in the regions. Further, obstacles to effective evaluation arise from the lack of data comparability, the rigidity of time-scales and a focus on performance approaches.

However, in order to evaluate the perspectives of the economics of the country, it is purposeful to analyse its development of the recent years.

Gross domestic product (GDP) made 34.6 billion euro in 2013 and increased almost 90 per cent since 2004. The real GDP growth during this period was influenced on the whole economic situation in the EU. Strong growth till 2008 stopped during the crisis, but the decrease of GDP was recorded only in 2009. Nevertheless the recovery of economics is hard and the growth of real GDP declines every year. 
GDP per capita also rose every year since 2005, except 2009 because of the influence of crisis. But its growth is decreasing. The growth of GDP per capita amounted to 14-21 per cent every year till 2009 while its growth after crisis decreased to 6-8 per cent per year except the growth of 14.3 per cent during the 2011. In spite of the recovery of GDP, the level of economics in Lithuania still remains 26 per cent lower than in the EU (Fig. 1).

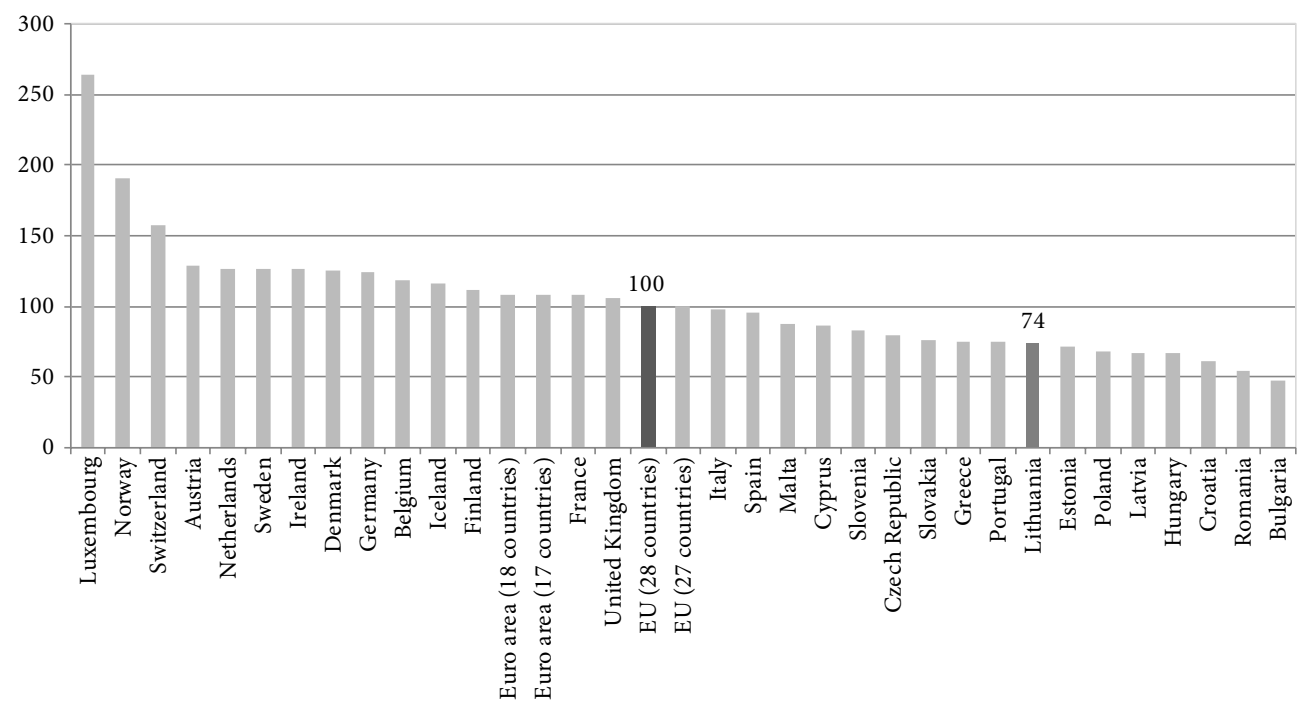

Fig. 1. GDP per capita in Lithuania in 2013 in comparison to the EU countries Source: made by authors according to the Eurostat data (2014).

International trade and direct foreign investment (FDI) are extremely important to the economies of EU member-states. The extent of country's participation in the international trade depends on its economics size and structure.

The growth of export and import is related with economic situation. Both of them grew quickly before the crisis. However the growth of both indicators in 2010 was even higher than before 2009, but it was the consequence of low export and import during the crisis. Unfortunately, the growth of both indicators is decreasing for the last three years. During 2013 import increases 5.3 per cent and export a bit more, i.e. 6.5 per cent.

In the context of the theories of cohesion and growth, the significant role is played by the investment in $\mathrm{R} \& \mathrm{D}$ and human resources. $\mathrm{R} \& \mathrm{D}$ expenditure as a percentage of GDP increases from 0.75 in 2004 till 0.95 in 2013.

Direct foreign investments amounted to 12.4 billion euro in 2013 and were the largest comparing with the previous years. On the other hand the growth of FDI during the last year was low and amounted to 2.4 per cent comparing with the 9-10 per cent increase of FDI during 2010-2012 and more than 20 per cent increase before the crisis (Fig. 2).

The biggest part of FDI - 24.7 per cent - was attracted by manufacturing sector and 24.3 per cent by financial services, 12.5 per cent flowed to real estate, 10.2 per cent to wholesale and retail. In 201382.2 per cent of FDI came from the EU. The biggest part of investment in 


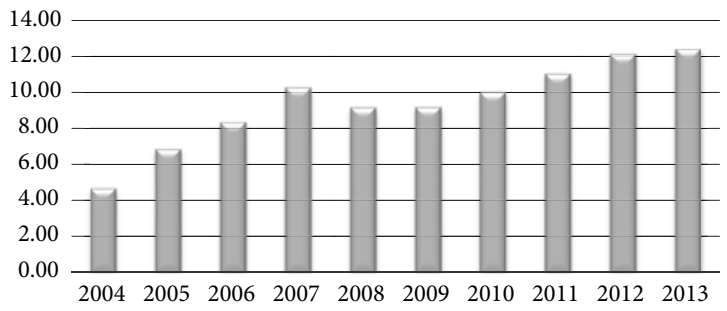

Fig. 2. FDI in billion euro during 2004-2013

Source: made by authors according to Lithuanian Statistics data (2014).

Lithuania was made by Sweden (23.7 per cent of all FDI), Poland (10.1 per cent of all FDI), Germany (10.1 per cent of all FDI), the Netherlands (8.7 per cent of all FDI), EFTA countries (8.7 per cent of all FDI), Norway (6.2 per cent of all FDI) and Denmark (5.6 per cent of all FDI).

Figure 3 presents FDI intensity (average value of inward and outward foreign direct investment flows divided by GDP and multiplied by 100) in all the EU member-states during 2013. Lithuanian FDI intensity amounted to 0.7, which is almost 4 times lower than the average of 28 EU countries.

The increasing inflation before the crisis stopped and reversed after it. It reached the lowest level during nine years in 2013 when it amounted to 0.4 . The level of average annual inflation was mostly determined by the rise of the prices of financial services by 16.8 per cent, actual rentals for housing by 6.5 per cent, pre-primary and primary education by 5.9 per cent, water supply and miscellaneous services relating to the dwelling by 5.8 per cent as well as accommodation services by 5.6 per cent.

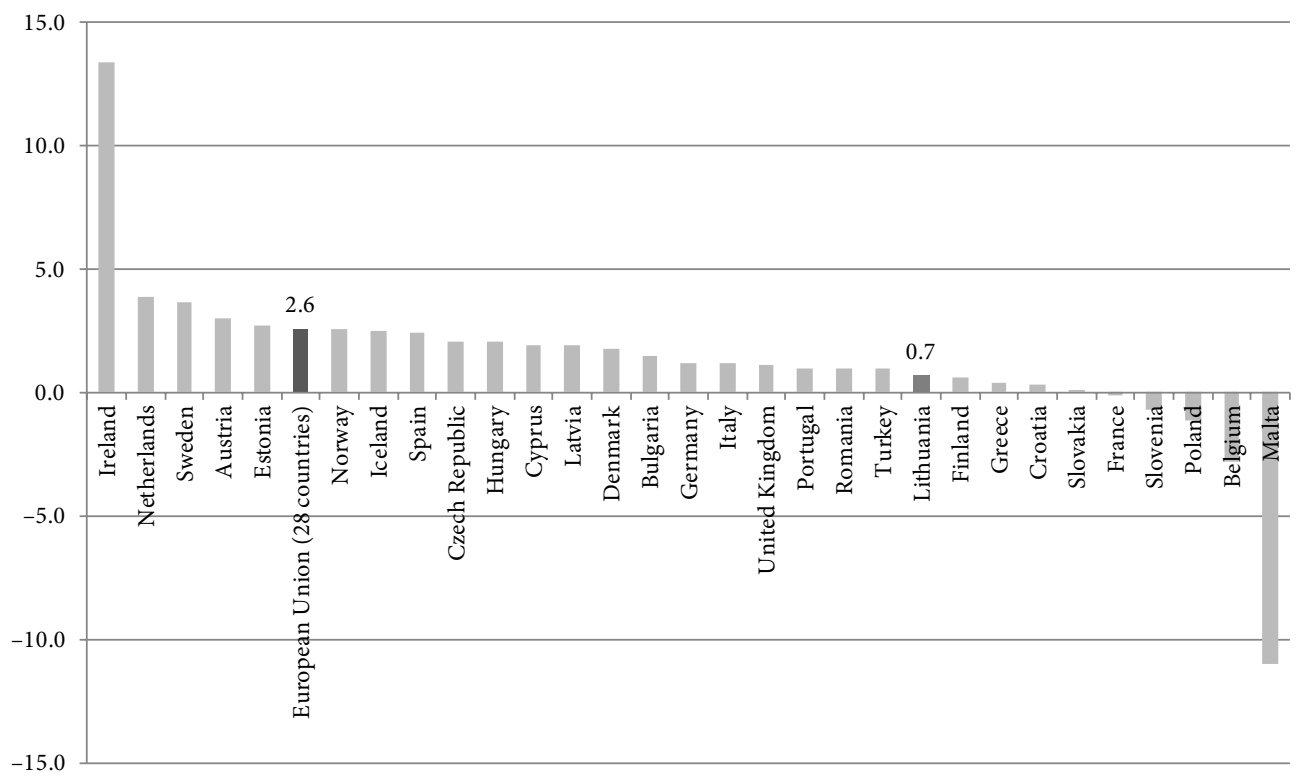

Fig. 3. Direct foreign investment as a percentage of GDP in 2013

Source: made by authors according to the Eurostat data (2014) 
The average monthly wage in Lithuania also increases after the crisis. The growth of average monthly wage in 2013 was the largest during the last five years and amounted to 5.1 per cent till 646 euro. The average monthly wage increased twice during the last ten years, but nevertheless it is one of the lowest in the EU. Minimal monthly wage also increased twice during the same period till 289.62 Lt. However, current minimal wage in Lithuania is also one of the lowest among the EU member-states. Only Bulgaria and Romania have lower wage making respectively 173.84 EUR and 205.34 EUR (data of 2014).

Summarizing, the main Lithuanian macroeconomic indicators are presented in Table 1.

Table 1. The main macroeconomic indicators

\begin{tabular}{ccccccc}
\hline Indicators & $\begin{array}{c}\text { Real GDP } \\
\text { growth, } \\
\text { per cent }\end{array}$ & $\begin{array}{c}\text { Inflation } \\
\text { (annual average), } \\
\text { per cent }\end{array}$ & $\begin{array}{c}\text { Gross average } \\
\text { earnings, euro }\end{array}$ & $\begin{array}{c}\text { Unemployment } \\
\text { rate, per cent }\end{array}$ & $\begin{array}{c}\text { Growth } \\
\text { of export, } \\
\text { per cent }\end{array}$ & $\begin{array}{c}\text { Growth } \\
\text { of import, } \\
\text { per cent }\end{array}$ \\
\hline 2005 & 7.8 & 3 & 369.61 & 8.3 & 26.9 & 25.5 \\
\hline 2006 & 7.8 & 4.5 & 433.18 & 5.8 & 18.7 & 23.5 \\
\hline 2007 & 9.8 & 8.1 & 522.01 & 4.2 & 11.1 & 15.4 \\
\hline 2008 & 2.9 & 8.5 & 623.18 & 5.8 & 28.5 & 18.7 \\
\hline 2009 & -14.8 & 1.3 & 595.46 & 13.8 & -26.6 & -37.9 \\
\hline 2010 & 1.6 & 3.8 & 575.79 & 17.8 & 32.7 & 34.5 \\
\hline 2011 & 6 & 3.4 & 592.53 & 15.4 & 28.8 & 29.3 \\
\hline 2012 & 3.7 & 2.8 & 615.09 & 13.4 & 14.4 & 9 \\
\hline 2013 & 3.3 & 0.4 & 646.34 & 11.8 & 6.5 & 5.3 \\
\hline
\end{tabular}

Source: Lithuanian Statistics (2014), Eurostat (2014).

\section{The volume of structural support}

Lithuania is getting the support from EU funds for already ten years. 907 million euro was got during 2004-2006 and 6775.5 million euro was got during 2007-2013. Taking into account all the period of both programs, i.e. 2000-2013, Lithuania got 1.3 per cent of all the funds intended for EU countries and it is the median value comparing with other EU countries.

But if we look at the sum got for one inhabitant of the country the support got by Lithuania is much higher comparing with the other countries. It is in the 6th place of all 28 EU countries. Only the support for Portugal, Greece, Estonia, Czech Republic and Hungary was higher (Fig. 4).

The period of 2007-2013 covers four operational programs. Operational program for the development of human resources is aimed at mobilisation of all Lithuanian working-age population because the investment in knowledge, abilities, activeness and entrepreneurship of Lithuanian people ensures the long-term growth of the economics of the country. 13.8 per cent of the EU structural support funds are assigned for this operational program. The largest share of the support - 45.72 per cent of the funding - is intended for the operational program for the economic development. 10 per cent of the funding is intended to be assigned for the scientific research of the country's economic competitiveness, economic growth and technological development. 39.08 per cent of all EU structural support planned for the period 


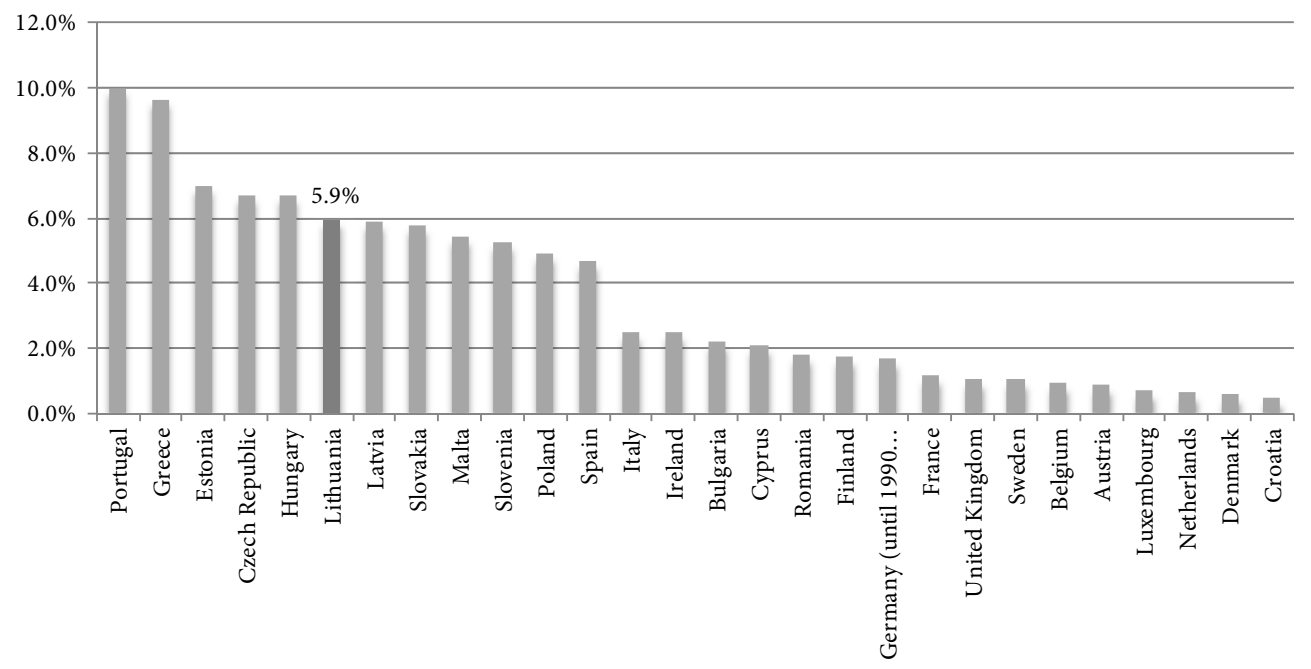

Fig. 4. European Commission funding per capita as a percentage of all the funds intended for EU countries during the period 2004-2013

Source: made by authors according to the Eurostat data (2014).

of 2007-2013 is intended to be assigned for the cohesion operational program which is designed to promote the development of sustainable society: living environment and quality improvement, reduction of regional gaps. The operational program for technical support is a special, additional operational program which is designed to administer topical operational programs. 1.4 per cent of the EU structural funding is intended for this operational program.

\section{Correlation and causality analysis between funding and economic and social indicators of Lithuania}

As the EU support for Lithuania lasts already for a decade it is useful to define its benefit to the economics of the country. For this reason the correlation analysis between funds and economic and social indicators of Lithuania was made. The correlation coefficients and the probabilities of Student criterion (probabilities that correlation coefficients are not significant) are presented in Table 2 .

One of the main indicators of the country is GDP. Lithuanian GDP and GDP per capita have strong correlation with funding, but they also increased till 2004 and the rate of their growth was similar. So it is hard to say whether it is the benefit of the EU support.

The same can be said with R\&D expenditure as percentage of GDP. It has quite strong correlation with funding, but it also increased till 2004 and the rate of its growth remained similar.

At-risk-of-poverty gap and at-risk-of-poverty rate is also decreasing in the long time period, but correlation between funding and these indicators is insignificant.

Positive correlation between funding and unemployment got because of the growing unemployment in 2007-2010. Nevertheless a good thing is that the unemployment decreases for the last three years. 
Table 2. Correlation coefficients with original values of the data and differenciated data and their significance

\begin{tabular}{lcccc}
\hline \multirow{2}{*}{ Economic indicator } & \multicolumn{2}{c}{$\begin{array}{c}\text { Correlations with original } \\
\text { values }\end{array}$} & \multicolumn{2}{c}{$\begin{array}{c}\text { Correlations after } \\
\text { differentiation }\end{array}$} \\
\cline { 2 - 5 } & $\begin{array}{c}\text { Correlation } \\
\text { coefficient }\end{array}$ & $\begin{array}{c}\text { Probability } \\
|\mathrm{t}|=0\end{array}$ & $\begin{array}{c}\text { Correlation } \\
\text { coefficient }\end{array}$ & $\begin{array}{c}\text { Probability } \\
|\mathrm{t}|=0\end{array}$ \\
\hline Population & -0.96 & 0.0000 & 0.04 & 0.9079 \\
\hline Emigration & 0.13 & 0.7148 & 0.05 & 0.9101 \\
\hline At-risk-of-poverty gap & -0.27 & 0.5151 & -0.20 & 0.6982 \\
\hline At-risk-of-poverty rate & -0.52 & 0.1896 & -0.62 & 0.1897 \\
\hline Unemployment & 0.50 & 0.1428 & -0.21 & 0.6208 \\
\hline Gross average earnings & 0.96 & 0.0000 & 0.05 & 0.9050 \\
\hline Net average earnings & 0.96 & 0.0000 & 0.06 & 0.8863 \\
\hline R\&D expenditure as percentage of GDP & 0.82 & 0.0072 & 0.21 & 0.6519 \\
\hline GDP at the current prices & 0.92 & 0.0002 & 0.06 & 0.8861 \\
\hline GDP per capita & 0.94 & 0.0000 & 0.13 & 0.7529 \\
\hline Export & 0.91 & 0.0001 & -0.22 & 0.5927 \\
\hline Import & 0.87 & 0.0005 & -0.07 & 0.8702 \\
\hline Labor productivity per hour & 0.98 & 0.0000 & 0.21 & 0.6249 \\
\hline Labor productivity per one \\
employed person
\end{tabular}

Source: authors' calculations.

Gross average earnings and net average earnings are strongly correlated with funding, but the increase of these economic indicators could be caused by the general reasons related with the joining to the EU. These indicators also didn't escape the fall during the crisis in 2009-2010.

The funds still don't help to solve the demographic problems. Population decreases and emigration increases every year. Good thing is that the number of emigrant decreased in 2011-2013, but more time is needed in order we can say that it is a new (good) tendency.

The export, import, growth of labor productivity per hour and labor productivity per one employed person, contrary to most other indicators, became faster from 2004. Nevertheless these indicators also couldn't avoid the reduction in 2009.

Similar situation is with direct foreign investment and direct foreign investment per inhabitant. They also grew faster from 2004, except the decline in 2008. Of cause it could be caused by the general reasons related with the joining to the EU.

The number of companies with 5-9 employees is the most stable comparing with the other size of companies and growing slightly every year except of the slight decrease in 2011 and 2012 years. Number of very small companies with 4 or less employees also increases but with more significant fluctuations. Meanwhile the number of larger companies that have 10 or more employees is recently decreasing and correlation with funding is insignificant.

Although the correlation between turnover of the companies and funding is insignificant, it is hard to evaluate it correctly because of the absence of the turnover data from 2012 year. 
The linear or non-linear regression model could better show the relationship between funding and economic indicators. But the problem is that most of these economic indicators are not stationary processes at the significant level 0.05 . That's why spurious regression model i.e. incorrect results can be got. Unit root test showed that only population, number of all companies, number of companies with 5-9 employees and number of companies with 10-19 employees are stationary. Population is stationary process without trend and intercept. Number of all companies, number of companies with 5-9 employees and number of companies with 10-19 employees are stationary when the intercept is included into the equation. Emigration, turnover, GDP, unemployment, export, import, R\&D expenditure as percentage of GDP, at-risk-of-poverty gap, direct foreign investment per inhabitant, number of companies with 0-4 employees, number of companies with 150-249 employees, number of companies with 250-499 employees, number of companies with 500-999 employees, number of companies with 1000 employees and more become stationary after the first-order differentiation without trend and intercept. Number of companies with 20-49 employees becomes stationary after the first-order differentiation with linear trend and intercept. All others, i.e. funding, gross average earnings, net average earnings, GDP per capita, labor productivity per hour, labor productivity per one employed person, at-risk-of-poverty rate, direct foreign investment, number of companies with 50-99 employees, number of companies with 100-149 employees become stationary after the second-order differentiation without trend and intercept.

In order to avoid spurious regression the not-stationary economic indicators were differenciated in order to get stationary processes and correlation coefficient were recalculated (Table 2). The results show that only correlation coefficient between funding and direct foreign investment per inhabitant remains significant at the significant level 0.05. It means that the changes in funding have the significant impact only on the changes in direct foreign investments per inhabitant. Recently the investments from European Union accounts for about 80 per cent of all direct foreign investments so it is very important source for Lithuania (the support from the EU funds that are analysed in this research accounts for almost 12 per cent of all investments from EU).

The simple linear regression model between these indicators can be written as:

$$
\Delta I_{t}=914.2653+5.3265 \cdot \Delta^{2} F_{t} .
$$

Here $\Delta I_{t}$ is the first-order differenciated direct foreign investments per inhabitant at the time moment $t$ and $\Delta^{2} F_{t}$ is the second-order differenciated funds at the time moment $t$. This also can be written as:

$$
I_{t}=I_{t-1}+914.2653+5.3265 \cdot\left(F_{t}-2 F_{t-1}+F_{t-2}\right) .
$$

It means that direct foreign investments per inhabitant at the time moment $t$ depends on the direct foreign investments per inhabitant at the previous $(t-1)$ time moment and on the funding at the time moments $t, t-1$ and $t-2$. The parameters and the model are significant and the coefficient of determination $\left(R^{2}\right)$ of this model is 0.70 . The residuals of this model satisfy the needed requirements:

1. The mean of residuals is equal to 0 .

2. The residuals are distributed by normal distribution. The Jargue-Bera criterion is equal to 0.66 and its probability is 0.73 . 
3. The residuals are homoscedastic. $n R^{2}$ statistics by Breusch-Pagan_Godfrey test is 0.02 and the probability of $\chi^{2}(1)$ is equal to 0.89 .

4. The correlogram shows that the residuals are not correlated.

It means that this model is suitable for prediction.

Funding for regional and cohesion policy in 2014-2020 amount to €6823.1 million for Lithuania. This is slightly more than in the period 2007-2013. If the funding in 2014 will be the same as in 2013, according to the given regression model the direct foreign investments this year should be 15,001 Lt (4345 euro) per inhabitant, i.e. 3.2 per cent higher than in the previous year. Meanwhile it is hard to predict the other economic indicators as their changes are influenced by other factors, not funding itself. Of cource funding can hardly make the great influence on economics as these sums are not very large. Recently it accounts for about 3.0-3.5 per cent of all GDP of the region. Nevertheless it is very important to ensure the efficient use of these funds in order to get the maximum benefit from this support.

In order to confirm the results above Granger causality test was made. Lag length was chosen 2 in order to evaluate the time over which one of the variables could help predict the other. It was the largest lag length that was suitable for all data series. The results are presented in Table 3.

Table 3. The results of Granger causality test

\begin{tabular}{lcc}
\hline \multirow{2}{*}{ Economic or social indicator $(\mathrm{y})$} & \multicolumn{2}{c}{ Probability of Null Hypothesis when lag is 2: } \\
\cline { 2 - 3 } & $\begin{array}{c}\text { Funds do not } \\
\text { Granger-cause } y\end{array}$ & $\begin{array}{c}y \text { does not } \\
\text { Granger-cause Funds }\end{array}$ \\
\hline Population & 0.8728 & 0.6167 \\
\hline Emigration & 0.3853 & 0.5426 \\
\hline At-risk-of-poverty gap & 0.9930 & 0.4143 \\
\hline At-risk-of-poverty rate & 0.7915 & 0.1868 \\
\hline Unemployment & 0.1011 & 0.8799 \\
\hline Gross average earnings & 0.1583 & 0.9579 \\
\hline Net average earnings & 0.1589 & 0.9412 \\
\hline R\&D expenditure as percentage of GDP & 0.1662 & 0.5405 \\
\hline GDP at the current prices & 0.3048 & 0.9290 \\
\hline GDP per capita & 0.4371 & 0.8848 \\
\hline Export & 0.6603 & 0.9345 \\
\hline Import & 0.5444 & 0.8966 \\
\hline Labor productivity per hour & 0.8400 & 0.7896 \\
\hline Labor productivity per one employed person & 0.6119 & 0.8608 \\
\hline Direct foreign investment & 0.0372 & 0.2572 \\
\hline Direct foreign investment per inhabitant & 0.0479 & 0.3236 \\
\hline Number of all companies & 0.4397 & 0.5015 \\
\hline Turnover of the companies & 0.7406 & 0.8445 \\
\hline Sorce: & &
\end{tabular}

Source: authors' calculations. 
The results show that EU funds do not Granger-cause all the indicators that are analysed in this research except direct foreign investment (total and per capita). It leads to the conclusion that EU support lets increase only direct foreign investment, but it doesn't help to increase the GDP and other economic indicators and there can be stated that funds are not used effectively.

\section{Conclusions}

The use of the EU funds in Lithuania provides the opportunity to invest, restructure the public sector and promote investment in the private sector which would be complicated without the EU support. An appropriate use of funds increases competitiveness of the country and makes the conditions for the faster economic growth.

The EU structural funds can also cause the adverse economic effects such as competition distortions, private investment dislodging, price increase, lower efficiency of the budget, demotivation of the private sector, preconditions for corruption.

Although the absorption of the EU funds is rather prompt in Lithuania in comparison to other EU member-countries, Lithuania is still lagging behind the plans. It is necessary to plan the fund absorption during the period of the next few years and estimate the risk that not all the EU funds will be timely absorbed. In this case, in order to improve the absorption of the EU funds, the EU fund transfers should be revised and directed from one instrument to another or assigned to other priorities.

It is necessary to revise the priorities of the EU funding as well as the measures of the support absorption because it would enable to solve the most topical Lithuanian economic problems such as the youth unemployment, emigration, unequal income distribution and so forth.

The detailed analysis of correlation between funding and economic and social indicators of Lithuania showed that there is significant relationship between the funding and the direct foreign investments per inhabitant. Granger causality test also confirm that EU funds Granger-cause direct foreign investment (total and per capita). The regression model that was created showed that if the funding in 2014 will be the same as in 2013, the direct foreign investments this year should be 4345 euro per inhabitant, i.e. 3.2 per cent higher than in the previous year. The significant correlation between EU support and other economic and social indicators was not found. Nevertheless the EU funding is undoubtedly useful and necessary to promote the economic growth. The largest problem and task is to ensure the efficiency of the use of EU funds, that lets achieve the maximum benefit for the economics of Lithuania.

\section{References}

Bachtler, J.; Wren, C. 2006. Evaluation of European Union Cohesion policy: research questions and policy challenges, Regional Studies 40(2): 143-153. http://dx.doi.org/10.1080/00343400600600454

Bachtler, J.; Gorzelak, G. 2007. Reforming EU Cohesion policy. A reappraisal of the performance of the Structural Funds, Policy Studies 28(4): 309-326. http://dx.doi.org/10.1080/01442870701640682

Basile, R.; Castellani, D.; Zanfei, A. 2007. Location choices of multinational firms in Europe: the role of EU cohesion policy, Journal of International Economics 74(2): 328-340.

http://dx.doi.org/10.1016/j.jinteco.2007.08.006 
Batterbury, S. C. E. 2006. Principles and purposes of European Union Cohesion policy evaluation, Regional Studies 40(2): 179-188. http://dx.doi.org/10.1080/00343400600600504

Bouayad-Agha, S.; Turpin, N.; Vedrine, L. 2013. Fostering the development of European regions: a spatial dynamic panel data analysis of the impact of cohesion policy, Regional Studies 47(9): 1573-1593. http://dx.doi.org/10.1080/00343404.2011.628930

Cartwright, W. R. 2001. Multiple linked 'Diamonds' and the international competitiveness of export-dependent industries: the New Zealand experience, Management International Review 33: 55-70.

Cho, D. S. 2004. From national competitiveness to bloc and global competitiveness, Competitiveness Review 8(1): 11-23. http://dx.doi.org/10.1108/eb046358

Dumciuviene, D. 2011. Economic development and cohesion policy as financial instrument, in The 16th International Conference "Economics and Management", 27-29 April 2011, Brno. Program and reviewed abstract book. Brno University of Technology, 55-56.

Eckel, C. 2007. Globalization and specialization, Journal of International Economics 75(1): 219-228. http://dx.doi.org/10.1016/j.jinteco.2007.08.007

Ederveen, S.; Groot, H. L. F.; Nahuis, R. 2006. Fertile soil for structural funds? A panel data analysis of the conditional effectiveness of European cohesion policy, Kyklos 59(1):17-42.

http://dx.doi.org/10.1111/j.1467-6435.2006.00318.x

Enguix, M. R. M.; Garcia, J. G.; Gallego, J. C. G. 2012. An impact analysis of the European structural funds on the variation of the rate of employment and productivity in objective 1 regions, European Planning Studies 20(4): 321-340. http://dx.doi.org/10.1080/09654313.2012.650907

Eurostat [online]. 2014 [cited 19 September 2014]. Available from Internet: http://ec.europa.eu/eurostat

Farrell, M. 2004. Regional integration and cohesion - lessons from Spain and Ireland in the EU, Journal of Asian Economics 14(6): 927-946. http://dx.doi.org/10.1016/j.asieco.2003.09.004

Hall, R.; Smith, L. 2001. Competitiveness and cohesion in EU policies. Oxford University Press, 108-146.

Hassler, J.; Krusell, P.; Storesletten, K.; Zilibotti, F. 2005. The dynamics of government, Journal of Monetary Economics 52(7): 1331-1358. http://dx.doi.org/10.1016/j.jmoneco.2005.08.012

Katsaitis, O.; Doulos, D. 2009. The impact of EU structural funds on FDI, Kyklos 62(4): 563-578. http://dx.doi.org/10.1111/j.1467-6435.2009.00451.x

Krugman, P. 2003. Rethinking international trade. Cambridge, MA: MIT Press.

Kutan, A. M.; Yigi, T. M. 2007. European integration, productivity growth and real convergence, European Economic Review 51(6): 1370-1395. http://dx.doi.org/10.1016/j.euroecorev.2006.11.001

Leonardi, R. 2006. Cohesion in the European Union, Regional Studies 40(2): 155-166. http://dx.doi.org/10.1080/00343400600600462

Lithuanian Statistics [online]. 2014 [cited 7 October 2014]. Available from Internet: http://osp.stat.gov.lt/ Lydeka, Z.; Gineitas, A. 1994. Verslo raida Lietuvoje, Inžinerine ekonomika 5: 30-38.

Maynouabc, L.; Saezab, M.; Kyriacoud, A.; Bacaria, J. 2014. The impact of structural and cohesion funds on Eurozone convergence, 1990-2010, Regional Studies (in press).

Mendez, C. 2011. The lisbonization of EU cohesion policy: a successful case of experimentalist governance?, European Planning Studies 19(3): 519-537. http://dx.doi.org/10.1080/09654313.2011.548368

Mendez, C. 2013. The post-2013 reform of EU cohesion policy and the place-based narrative, Journal of European Public Policy 20(5): 639-659. http://dx.doi.org/10.1080/13501763.2012.736733

Ministry of Finance of the Republic of Lithuania. 2010a. Galutine Lietuvos 2004-2006 metu bendrojo programavimo documento igyvendinimo ataskaita. Vilnius, Lithuania [online], [cited 22 October 2014]. Available from Internet: http://www.esparama.lt/vertinimo-ataskaitos

Ministry of Finance of the Republic of Lithuania. 2010b. Single Programming Document of Lithuania 2004-2006. [online], [cited 29 November 2014]. Available from internet: http://www.transp.lt/en/ eu_support/stuctural_funds/single_programming_document 
Mirosnika, K.; Petkovovaa, L.; Cadil, J. 2014. Statistical analysis of cohesion funding in the Czech Republic, Procedia Economics and Finance 12: 437-444. http://dx.doi.org/10.1016/S2212-5671(14)00365-7

Mohl, P.; Hagen, T. 2010. Do EU structural funds promote regional growth? Evidence from various panel data approaches, Regional Science and Urban Economics 40(5): 353-365. http://dx.doi.org/10.1016/j.regsciurbeco.2010.03.005

Rehme, G. 2006. Redistribution and economic growth in integrated economies, Journal of Macroeconomics 28(2): 392-408. http://dx.doi.org/10.1016/j.jmacro.2004.07.006

Rodríguez-Pose, A.; Fratesi, U. 2004. Between development and social policies: the impact of European structural funds in objective 1 regions, Regional Studies 38(1): 97-113. http://dx.doi.org/10.1080/00343400310001632226

Rugman, A.; D'Cruz, J. 2005. The 'double diamond' model of international competitiveness: the Canadian experience, Management International Review 33: 17-39.

Shelton, C. A. 2007. The size and composition of government expenditure, Journal of Public Economics 91(11-12): 2230-2260. http://dx.doi.org/10.1016/j.jpubeco.2007.01.003

Snieska, V. 2008. Research into international competitiveness in 2000-2008, Inzinerine ekonomika - Engineering Economics 4(59): 29-41.

Snieska, V. 2002. Klasteriai: raktas ị regionų konkurencingumo didinimą, Inzinerinè ekonomika - Engineering Economics 1(18): 57-61.

Treaty of Lisbon. 2007. Amending the Treaty on European Union and the Treaty Establishing the European Community, Official Journal of the European Union.

Daiva DUMCIUVIENE, Prof., PhD in Social Sciences (Economics), Department of Economics, School of Economics and Business, Kaunas University of Technology. The main areas of research are international integration, competitiveness and cohesion, economic growth. Publications: author of more than 30 research papers.

Alina STUNDZIENE, Assoc. Prof., PhD in Social Sciences (Economics), Department of Economics, School of Economics and Business, Kaunas University of Technology. The main areas of research are econometric models, economic forecasting, analysis of business environment, financial analysis and evaluation of the performance of the companies. Publications: author of about 10 research papers. 